\title{
FIELD STUDIES ON COLIPHAGES AND COLIFORMS AS INDICATORS OF AIRBORNE ANIMAL VIRAL CONTAMINATION FROM WASTEWATER TREATMENT FACILITIES
}

\author{
K. F. Fannin,* J. J. Gannon, K. W. Cochrait and \\ J. C. SPEndLove \\ Department of Environmental and Industrial Health and of Epidemiology. School of Public Health. \\ The University of Michigan, Ann Arbor, Michigan 48109, and Dugway Proving Ground, \\ Dugway, Utah 84022 , U.S.A.
}

(Received 12 August 1976)

\begin{abstract}
The occurrence of animal viruses in the aerosol emissions of wastewater treatment facilities was evaluated by direct assay and by the use of coliforms and coliphages as indicator organisms. Coliforms and coliphages were compared and evaluated with regard to their suitability as indicators of airborne animal viral contamination from wastewater treatment facilities. Two plants, one with treatment by activated sludge and the other by trickling filtration, were studied. Field air sampling procedures used large-volume air samplers, with recirculation devices, and Andersen samplers. Airborne viruses were enumerated by a most probable number (MPN) procedure. Partially treated liquid sewage contained about $1.0 \times 10^{2}$ pfu $1^{-1}$ of animal viruses assayed on Buffalo Green Monkey (BGM) cells, $3.6 \times 10^{5}$ and $5.0 \times 10^{5}$ pfu $1^{-1}$ of coliphages, depending upon the $E$. coli host strain used for assay, and $2.0 \times 10^{9}$ colonies $1^{-1}$ of coliform bacteria. No airborne animal viruses were recovered, airborne coliphage levels averaged $2.3 \times 10^{-1}$ and $3.0 \times 10^{-1} \mathrm{MPN} \mathrm{m}^{-3}$, coliforms from aerosol emissions were $2.1 \times 10^{2}$ colonies $\mathrm{m}^{-3}$. Ratios of coliphages to animal viruses indicate that wastewater treatment plants may be continuous sources of low level concentrations of animal virus aerosols. Evidence shows coliforms to be much less stable than coliphages in the airborne state. Coliphages may be a more acceptable indicator of airborne animal viral contamination than coliforms.
\end{abstract}

\section{INTRODUCTION}

Certain bacteria have been shown to be emitted in relatively high concentrations from wastewater treatment facilities (Randall and Ledbetter, 1966). Although animal viruses, many of which are pathogenic, have been shown to occur throughout the processes of wastewater treatment, their airborne emission from these sources has not been evaluated. Since animal viruses are probably present in these airborne emissions in very low concentrations, the use of indicator organisms such as coliforms or coliphages may be suitable for early estimates of the levels.

The use of coliphages as indicators of animal viral water pollution has been advocated by Kott et al. (1969). Metcalf et al. (1970) pointed out, however, that it may be difficult to establish the validity of coliphages as viral indicators, since they may be present in high numbers even when enteroviruses are in low concentrations or absent. But, since coliphages behave similarly to the enteroviruses and are more resistant to environmental stresses than are the coliforms, it has been argued that they may be used to evaluate more accurately the effectiveness of waste-

* Present address: Life Sciences Research Division, IIT Research Institute, 10 West 35 th Street, Chicago, Illinois 60616, U.S.A. water treatment than the traditional bacterial indicator organisms (Kott et al. 1969).

Caution must be observed in the use of a nonpathogenic organism as a model for the behavior of a pathogenic one (Metcalf, 1969). But increasing evidence indicates that, under certain conditions, some environmental factors may similarly influence the survival of both bacterial and animal viruses. Kott $e t$ al. (1969), for example, cited evidence that the T-1 to $\mathrm{T}-7$ coliphage group is as resistant to the natural killing properties of sea water as are the enteroviruses. These findings were supported by Metcalf et al. (1970), who found that coliphage was able to survive at least as long as coxsackievirus B-3 in estuaries and in shellfish. Much of the effort to determine the stability of coliphages and to study their suitability as animal virus models has been directed toward the $T$ bacterial viruses. The study of aerosols of these $T$-phages has shown marked variations in the stability of various airborne agents within this group. Harstad (1965) found that T-1 phage aerosols were more stable than those of T-3 phage. Ehrlich et al. (1964) showed that the survival of airborne $\mathrm{T}-3$ phage was similar to Rous-sarcoma virus and poliomyelitis virus, with higher survival rates at higher levels of relative humidity.

Other investigators have maintained, however, that the more recently isolated small RNA phages (Loeb, 
1959; Davis et al. 1961) may be better models of the enteroviruses than are the T-phages. since they share a greater number of similar characteristics. Olivieri (1974), for example, advocated the use of $f_{2}$ phage as an enterovirus model by stressing its similarities with poliovirus and its ease of manipulation. Lefler and Kott (1974) found that $f_{2}$ phage survived longer in sand columns than poliovirus did. Kott et al. (1974) used $f_{2}$ and MS-2 phages as reference strains for studies on their resistance to environmental stress. They found $\mathrm{f}_{2}$ to be more resistant to chlorination in oxidation pond effluents than MS-2 phage, which was more resistant than poliovirus type 1 . This report did not, however, distinguish between free and combined chlorine. Scarpino (1975) clearly demonstrated poliovirus 1 and coxsackievirus $A 9$ to be more resistant than MS-2 or $f_{2}$ (which were more resistant than E. coli or T-5 phage) to inactivation by hypochlorous acid. He further pointed out that $f_{2}$ is more resistant than poliovirus 1 or coxsackievirus $A 9$ to inactivation in the presence of monochloramine. Dubovi and Akers (1970) supported the use of tailless bacteriophages such as DNA-containing S-13 and RNA-containing MS-2 instead of the $T$ bacterial viruses which possess a tail-like structure used in attachment to bacteria. They indicated that factors which damage this structure during aerosol studies may eliminate the infectious capacity of the particle. These authors found that, because of similarities in structure and in mechanism of the inactivation in this airborne state, these viruses were very similar to certain animal viruses and justifiable models for certain types of aerosol studies. While the intact MS-2 virus may be inactivated in aerosols, the infectivity of the RNA has been found to remain stable (Dubovi, 1971). This observation is similar to that observed with poliovirus (deJong et al., 1973).

Coliform bacteria have been used as indicators of fecal contamination of water for many years and their densities have been utilized as "criteria of the degree of pollution and thus of the sanitary quality of the sample under examination" (Standard Methods, 1971). Some investigators have suggested that these organisms would serve equally well as indicators of airborne contamination by wastewater treatment plants (Adams and Spendlove, 1970; Goff et al., 1973). Randall and Ledbetter (1966), however, suggested that Klebsiella would be a better indicator of bacterial air pollution from sewage sources, since these encapsulated bacteria are considered to be more capable of survival in the atmosphere than nonencapsulated ones. While such conclusions for Klebsiella may be valid, the procedures for their differentiation are generally more involved than those required for coliform observations. Since coliform organisms are universally accepted as indicators of fecal contamination, they were examined as possible indicators of contamination by airborne viruses from wastewater treatment plants. The purpose of this study is to evaluate animal virus occurrence in aerosol emissions from waste- water treatment facilities by direct assay and by the use of coliforms and coliphages as indicator organisms and to evaluate and compare the suitability of coliforms and coliphages as animal virus indicators.

\section{MATERIALS AND METHODS}

\section{Field sampling}

Two wastewater treatment plants were selected for the comparative study of airborne coliphages. coliforms and animal viruses. These plants have been described by Fan. nin et al. (1976) as plants No. 3, activated sludge, and 4 , trickling filter, both in southeastern Michigan. Airborne samples for coliphage and animal virus assay were taken with Large Volume Air Samplers (LVAS) manufactured by Litton Systems, Inc., Minneapolis, Minnesota, recirculating the phosphate sampling Huid (PSF), and processing samples as previously described (Fannin et al., 1976). Coliform bacteria were collected with battery-operated Andersen samplers which were loaded with glass Petri dishes, each containing $27 \mathrm{ml}$ of Endo agar.

\section{Sewage processing}

Liquid sewage samples were processed for animal viruses after a procedure described by Rao et al. (1972), with slight modification. A $500 \mathrm{ml}$ sample was blended at high speed in a Waring blender for $4 \mathrm{~min}$, followed by centrifugation at $940 \mathrm{~g}$ for $30 \mathrm{~min}$ at $4^{\circ} \mathrm{C}$, for the removal of gross particulate matter. The $\mathrm{pH}$ was adjusted to 3.0 with $0.3 \mathrm{~N} \mathrm{HCl}$, and the sample was centrifuged $13,400 \mathrm{~g}$ at $4^{\circ} \mathrm{C}$ for $30 \mathrm{~min}$. $\mathrm{AlCl}_{3}$ was added to the supernatant to a final concentration of $0.005 \mathrm{M}$. as described by Wallis et al. (1972). The sample was then slowly pressure filtered, using filtered air. through a $47 \mathrm{~mm}$ dia. Millipore filter. $0.45 \mu \mathrm{m}$ pore size. The filtering apparatus, with filter intact, was then transferred to a $50 \mathrm{ml}$ filtering flask. Five $\mathrm{ml}$ of $3 \%$ beef extract was added to the filter and placed at $4^{\circ} \mathrm{C}$ for $30 \mathrm{~min}$. Following this period, the remaining elution broth (beef extract solution) was pressure filtered into the flask. Samples for coliphage assay were obtained from the above sample following the $940 \mathrm{~g}$ centrifugation step and filtered as described by Fannin et al. (1976). A portion of the sample was also removed following the blending step for subsequent total coliform assay.

\section{Coliform and coliphage assays}

Airborne coliphage isolation and enumeration procedures used the most-probable-number (MPN) procedure described by Kott (1966) as modified (Fannin et al., 1976). The MPN method has been used to estimate phage concentrations at levels which were 100 - to 1000 -fold lower than could be detected by plaquing (Hoff and Jakubowski, 1966). Results are reported as $\mathrm{MPN} \mathrm{m}^{-3}$. Concentrations of airborne coliform bacteria containing particles were determined by colony counts of exposed Andersen sampler plates after incubation at $37^{\circ} \mathrm{C}$ for approximately $24 \mathrm{~h}$. All counts were corrected for positive hole counts as reported by Andersen (1958). Results are reported as colonies $\mathrm{m}^{-3}$. Liquid-borne coliphages were assayed by the soft agaroverlay method described by Adams (1959), using 2 replicates for each dilution. Plates were incubated for $5-18 \mathrm{~h}$, plaques were then counted and reported as plaque-forming units (pfu) per liter. Total coliform assay was performed according to Standard Methods for the Examination of Water and Wastewater (1971) by the membrane filter procedure, using 2 replicates at each dilution.

\section{Animal virus assays}

Since very low concentrations were anticipated, the MPN method was also used for the enumeration of air- 
borne animal viruses. Chang (1965) has discussed evidence that the MPN method is more sensitive to very low animal virus levels than is the plaque method. Animal viruses were assayed in cultures of Buffalo Green Monkey (BGM) cells using 10 tubes per processed airborne sample. Each tube was washed three times with the following solution: Hanks Balanced Salt Solution (HBSS), containing 200 units $\mathrm{ml}^{-1}$ penicillin. $200 \mu \mathrm{g} \mathrm{m} l^{-1}$ streptomycin. $1 \mu \mathrm{g} \mathrm{ml}^{-1}$ Fungizone. pH adjusted to $7.0-7.2$ with $7.5 \%$ sodium bicarbonate solution. After washing, $0.5 \mathrm{ml}$ of processed airborne sample was added to each tube. Control groups of 10 tubes each were inoculated; $0.5 \mathrm{ml}$ of HBSS or PSF were included. One milliliter of Minimum Essential Medium (MEM) containing $2 \%$ inactivated fetal calf serum was added to each tube. Tubes were capped, incubated at $37^{\circ} \mathrm{C}$ for 2 days and then checked microscopically for cytopathic effect (CPE). Each tube which showed CPE was subinoculated into other culture tubes three times for confirmation of positive virus isolation.

Liquid sewage samples were assayed for animal virus by plaquing on BGM cells in $2-0 z$ prescription bottles. Cell monolayers were washed three times as described above. Control bottles inoculated with HBSS or 3\% beef extract in HBSS were included in each test. Five-tenths milliliter of each sample-eluate or control was added to each of 10 culture bottles and spread evenly. After incubation for $1.5 \mathrm{~h}$ to permit virus absorption, cells were overlaid with $5 \mathrm{ml}$ of MEM plaquing medium, without neutral red. The MEM plaquing medium consisted of MEM in HBSS with $1.5 \%$ Bacto Agar, $1 \%$ of a $50 \%$ aqueous solution of $\mathrm{MgCl}_{2} \cdot 6 \mathrm{H}_{2} \mathrm{O}, 2 \%$ heat-inactivated fetal calf serum, 200 units $\mathrm{m}^{-1}$ penicillin, $200 \mu \mathrm{g} \mathrm{ml}^{-1}$ streptomycin, $1 \mu \mathrm{g} \mathrm{ml}^{-1}$ Fungizone; $\mathrm{pH}$ adjusted to $7.0-7.2$ with $7.5 \%$ solution of $\mathrm{NaHCO}_{3}$. The cultures were inverted, incubated at $37^{\circ} \mathrm{C}$ for 2 days, at which time they were overlaid with $4 \mathrm{ml}$ of MEM plaquing medium containing $4 \% 1: 1000$ neutral red, and incubated in the dark for 1 more day. Plaques were marked, counted and cultures incubated for 4 more days, with plaques being marked and counted at daily intervals. Virus concentration was expressed as plaque-forming units (pfu) per liter of liquid sewage.

Efficiency of recovery of animal virus from wastewater

Sewage influent was obtained from the influent trickling filter boom at wastewater treatment plant No. 4. This wastewater was then diluted into aliquots and autoclaved. A polio type 1 LSc2ab suspension was added to autoclaved wastewater. This sample was then processed according to the modified membrane filter concentration procedure as described above. Two-fold dilutions of the eluate in HBSS were assayed on BGM cells by the plaquing procedure described above. Eluate controls were included as 2-fold dilutions of $3 \%$ beef extract. Virus controls of an aliquot
Table 2. Efficiency of recovery of Polio 1 LSc2ab from sewage by membrane filter concentration procedure

\begin{tabular}{cccc}
\hline $\begin{array}{c}\text { Sewage } \\
\text { volume } \\
\text { (ml) }\end{array}$ & $\begin{array}{c}\text { Virus input } \\
\text { (pfu) }\end{array}$ & $\begin{array}{c}\text { Virus recovery } \\
\text { (pfu) }\end{array}$ & $\begin{array}{c}\text { Recovery } \\
(\%)\end{array}$ \\
\hline 240 & 1000 & 462 & 46 \\
240 & 1000 & 352 & 35 \\
230 & 390 & 228 & 58 \\
208 & 353 & 150 & 43 \\
\hline
\end{tabular}

Mean $=46 \%$.

of the original virus input were simultaneously assayed at 10-fold dilutions in HBSS. Plaques were counted and expressed as pfus. Percentage of recovery was determined by comparing the pfus recovered to actual pfu input.

\section{RESLLTS}

Average animal virus levels recovered from partially treated sewage, taken from trickling filter booms and activated sludge units of wastewater treatment plants, were $1.0 \times 10^{2} \mathrm{pfu} 1^{-1}$ (see Table 1). The efficiency of the animal virus concentration procedure used in this study averaged $46 \%$ of the total input of polia 1 LSc2ab from autoclaved sewage (see Table 2). Average coliphage levels in this sewage were $5.0 \times 10^{5} \mathrm{pfu}^{-1}$ for phages of $E$. coli $C 3000$ and $3.6 \times 10^{5} \mathrm{pfu}^{-1}$ for phages of $E$. coli $\mathrm{K} 12 \mathrm{HfrD}$ (see Table 1). As shown in Table 3, coliform organisms averaged $2.0 \times 10^{9}$ colonies $1^{-1}$ in these liquid sewage samples.

No airborne animal viruses were recovered from the environments studied. Average airborne coliphage

Table 3. Airborne coliforms related to liquid sewage concentration

\begin{tabular}{cccc}
\hline $\begin{array}{c}\text { Plant } \\
\text { No. }\end{array}$ & $\begin{array}{c}\text { Liquid sewage } \\
\text { concn. } \\
\text { (colonies/1) }\end{array}$ & $\begin{array}{c}\text { No. of } \\
\text { air } \\
\text { samples }\end{array}$ & $\begin{array}{c}\text { Mean airborne } \\
\text { concn. } \\
\text { (colonies/m }\end{array}$ \\
\hline 3 & $3.2 \times 10^{3}$ & 3 & $1.3 \times 10^{2}$ \\
3 & $3.2 \times 10^{8}$ & 1 & $1.8 \times 10^{2}$ \\
3 & $7.8 \times 10^{9}$ & 4 & $3.9 \times 10^{2}$ \\
4 & $1.5 \times 10^{9}$ & 4 & $7.9 \times 10^{1}$ \\
4 & $5.5 \times 10^{7}$ & 4 & $2.1 \times 10^{1}$ \\
Mean & $2.0 \times 10^{9}$ & & $2.1 \times 10^{2}$ \\
\hline
\end{tabular}

Table 1. Airborne viruses related to liquid sewage concentration

\begin{tabular}{|c|c|c|c|c|c|c|c|}
\hline \multirow[b]{3}{*}{$\begin{array}{l}\text { Plant } \\
\text { No. }\end{array}$} & \multicolumn{6}{|c|}{ Concentration of viruses assayed on: } & \multirow{3}{*}{$\begin{array}{c}\text { No. } \\
\text { of } \\
\text { air } \\
\text { samples }\end{array}$} \\
\hline & \multicolumn{2}{|c|}{ BGM Cells } & \multicolumn{2}{|c|}{ E. coli $\mathrm{C} 3000^{*}$} & \multicolumn{2}{|c|}{ E. coli $\mathrm{K} 12 \mathrm{HfrD}{ }^{*}$} & \\
\hline & $\begin{array}{l}\text { Sewage } \\
(\mathrm{pfu} / 1)\end{array}$ & $\begin{array}{c}\text { Air } \\
\left(\mathrm{MPN} / \mathrm{m}^{3}\right)\end{array}$ & $\begin{array}{l}\text { Sewage } \\
\text { (pfu/1) }\end{array}$ & $\begin{array}{c}\text { Air } \\
\left(\mathrm{MPN} / \mathrm{m}^{3}\right)\end{array}$ & $\begin{array}{l}\text { Sewage } \\
\text { (pfu/1) }\end{array}$ & $\underset{\left(\mathrm{MPN} / \mathrm{m}^{3}\right)}{\mathrm{Air}}$ & \\
\hline $\begin{array}{l}3 \\
3 \\
3 \\
4 \\
4\end{array}$ & $\begin{array}{c}7.0 \times 10^{1} \\
5.6 \times 10^{1} \\
\mathrm{ND}+ \\
1.1 \times 10^{2} \\
1.8 \times 10^{2}\end{array}$ & $\begin{array}{l}0 \\
0 \\
0 \\
0 \\
0\end{array}$ & $\begin{array}{l}5.9 \times 10^{4} \\
3.9 \times 10^{4} \\
7.4 \times 10^{4} \\
8.1 \times 10^{5} \\
8.8 \times 10^{5}\end{array}$ & $\begin{array}{r}2.6 \times 10^{-1} \\
1.1 \times 10^{-1} \\
\geq 5.1 \times 10^{-1} \\
\geq 2.9 \times 10^{-1} \\
1.9 \times 10^{-1}\end{array}$ & $\begin{array}{l}2.1 \times 10^{5} \\
1.5 \times 10^{5} \\
4.2 \times 10^{5} \\
5.8 \times 10^{5} \\
4.6 \times 10^{5}\end{array}$ & $\begin{aligned} & 1.7 \times 10^{-2} \\
& 0 \\
& 3.9 \times 10^{-1} \\
& \geq 3.8 \times 10^{-1} \\
& 1.4 \times 10^{-1}\end{aligned}$ & $\begin{array}{l}3 \\
1 \\
4 \\
4 \\
4\end{array}$ \\
\hline Mean & $1.0 \times 10^{2}$ & 0 & $5.1 \times 10^{5}$ & $3.0 \times 10^{-1}$ & $3.6 \times 10^{5}$ & $2.3 \times 10^{-1}$ & \\
\hline
\end{tabular}

* These data are taken in part from Fannin et al. (1976).

† Sample not assayed. 
Table 4. Comparison of ratios of Coliforms to coliphages from airborne emissions and liquid sewage

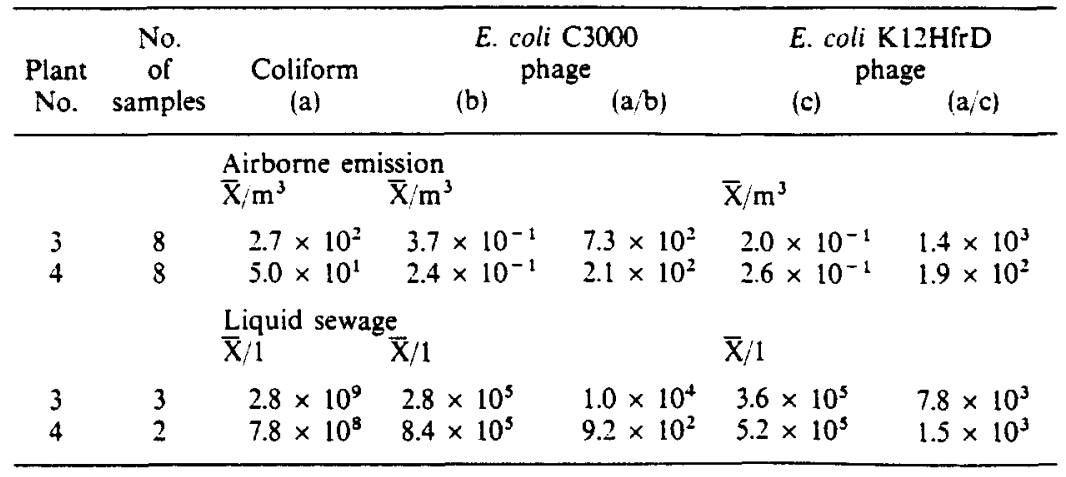

Table 5. Comparison of coliform/coliphage ratios of liquid sewage to airborne emissions

\begin{tabular}{|c|c|c|c|c|c|c|}
\hline \multirow[b]{2}{*}{$\begin{array}{l}\text { Plant } \\
\text { No. }\end{array}$} & \multicolumn{2}{|c|}{ E. coli $\mathrm{C} 3000^{*}$} & \multicolumn{3}{|c|}{$E$. coli $\mathrm{K} 12 \mathrm{HfrD}^{*}$} & \multirow[b]{2}{*}{$(c / d)$} \\
\hline & $\begin{array}{l}\text { Liquid sewage } \\
\text { ratio } \\
\text { (a) }\end{array}$ & $\begin{array}{l}\text { Airborne } \\
\text { ratio } \\
\text { (b) }\end{array}$ & $(a / b)$ & $\begin{array}{l}\text { Liquid sewage } \\
\text { ratio } \\
\text { (c) }\end{array}$ & $\begin{array}{l}\text { Airborne } \\
\text { ratio } \\
\text { (d) }\end{array}$ & \\
\hline 3 & $1.0 \times 10^{4}$ & $7.3 \times 10^{2}$ & 13.7 & $7.8 \times 10^{3}$ & $1.4 \times 10^{3}$ & 5.8 \\
\hline 4 & $9.2 \times 10^{2}$ & $2.1 \times 10^{2}$ & 4.4 & $1.5 \times 10^{3}$ & $1.9 \times 10^{2}$ & 7.8 \\
\hline
\end{tabular}

* Ratio includes coliphages as determined by this host.

Table 6. Airborne emissions of coliforms and coliphages compared to windspeed

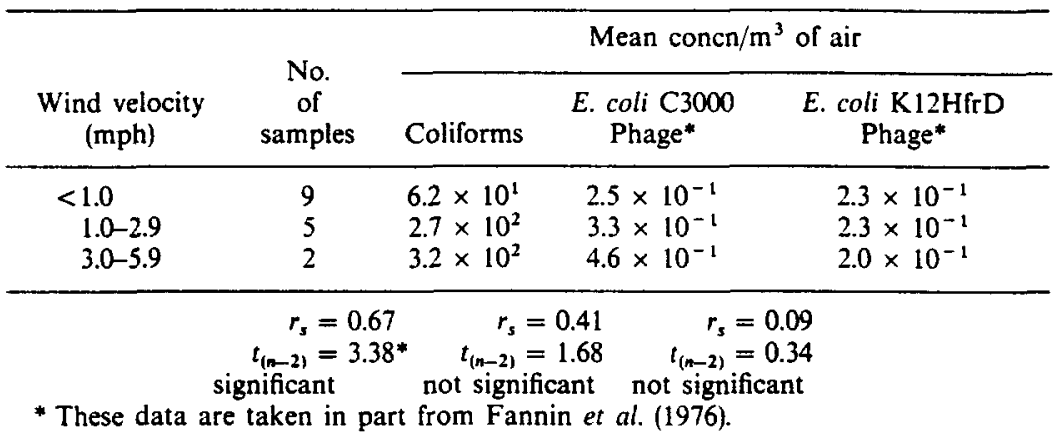

levels were $3.0 \times 10^{-1} \mathrm{MPN} \mathrm{m}^{-3}$ for $E$. coli C3000 phages and $2.3 \times 10^{-1} \mathrm{MPN} \mathrm{m}^{-3}$ for $E$. coli $\mathrm{K} 12 \mathrm{HfrD}$ phages. Average airborne coliform levels were $2.1 \times 10^{2}$ colonies $\mathrm{m}^{-3}$.

The mean ratio of airborne isolates to liquid sewage concentration was $6.0 \times 10^{-7}$ for E. coli $C 3000$ phage and $6.7 \times 10^{-7}$ for E. coli K12HfrD phage. Comparing these ratios to animal virus liquid sewage levels, when isolations were made, the expected airborne concentration of animal viruses would be approximately $6.2 \times 10^{-5}$ or $6.5 \times 10^{-5} \mathrm{MPN} \mathrm{m}^{-3}$, assuming that these viruses behave similarly to coliphages under the conditions studied. The mean airborne-to-liquid sewage coliform ratio was $1.1 \times 10^{-7}$, which is about $0.8 \mathrm{log}$ lower than that observed with the bacterial viruses. Comparing this ratio to animal virus liquid sewage levels, the expected airborne animal virus concentrations would be approximately $1.1 \times 10^{-5} \mathrm{MPN} \mathrm{m}^{-3}$. Thus. the estimates of the con-

* $95 \%$ confidence levels are used for determination of significance of all statistical tests in this investigation. centration of airborne animal virus, using a coliform bacteria ratio, would be about 0.8 log lower than those made with coliphage ratios.

An observation of the ratio of coliform bacteria to $E$. coli phage airborne isolates from plants Nos. 3 and 4 is shown in Table 4 . This ratio ranges from $1.9 \times 10^{2}$ at plant No. 4 to $1.4 \times 10^{3}$ at plant No. 3. Applying the Mann-Whitney $U$-test, as described by Siegel (1956), these data show that the probability of these ratios coming from the same population is 0.013 for those involving $E$. coli $C 3000$ phage and 0.001 for those obtained with $E$. coli $\mathrm{K} 12 \mathrm{HfrD}$ phage. That is, there is a significant difference between the ratio from these plants.*

This observation is examined further in Table 4 , where the ratio of coliform bacteria to coliphage in liquid sewage also appears greater in plant No. 3 than in plant No. 4 for the coliphages of both hosts examined. Comparing the liquid sewage ratios observed in Table 4 to the airborne ratios, Table 5 illustrates that, based upon these observations, the coliform-tocoliphage ratio in liquid sewage is consistently higher 
Table 7. Airborne emissions of coliforms and coliphages compared to ambient air temperature

\begin{tabular}{|c|c|c|c|c|}
\hline \multirow[b]{2}{*}{$\begin{array}{l}\text { Temp. } \\
(=C)\end{array}$} & \multirow{2}{*}{$\begin{array}{c}\text { No. } \\
\text { of } \\
\text { samples }\end{array}$} & \multicolumn{3}{|c|}{ Mean concn/m of air } \\
\hline & & Coliforms & $\begin{array}{l}\text { E. coli } \mathrm{C} 3000 \\
\text { Phage* }^{*}\end{array}$ & $\begin{array}{c}\text { E. coli } \mathrm{K} 12 \mathrm{HfrD} \\
\text { Phage }^{*}\end{array}$ \\
\hline $\begin{array}{l}15.0-19.9 \\
20.0-24.9 \\
25.0-29.9\end{array}$ & $\begin{array}{l}8 \\
6 \\
2\end{array}$ & $\begin{array}{l}2.5 \times 10^{2} \\
6.6 \times 10^{1} \\
8.3 \times 10^{1}\end{array}$ & $\begin{array}{l}3.5 \times 10^{-1} \\
3.0 \times 10^{-1} \\
1.0 \times 10^{-1}\end{array}$ & $\begin{array}{l}2.3 \times 10^{-1} \\
2.1 \times 10^{-1} \\
2.8 \times 10^{-1}\end{array}$ \\
\hline * These & $\begin{array}{r}r, \\
t(n-2) \\
\text { significa } \\
\text { re taken }\end{array}$ & $\begin{array}{c}-0.62 \\
.96^{*} \quad t_{1 n-} \\
\text { not si } \\
\text { part from }\end{array}$ & $\begin{array}{l}=-0.22 \quad r \\
=0.84 \\
\text { ficant not sig } \\
\text { anin et al. (1976 }\end{array}$ & $\begin{array}{l}-0.15 \\
.57 \\
\text { int }\end{array}$ \\
\hline
\end{tabular}

Table 8. Airborne emissions of coliforms and coliphages compared to relative humidity

\begin{tabular}{|c|c|c|c|c|}
\hline \multirow{2}{*}{$\begin{array}{c}\text { Relative } \\
\text { humidity } \\
(\%)\end{array}$} & \multirow{2}{*}{$\begin{array}{c}\text { No. } \\
\text { of } \\
\text { samples }\end{array}$} & \multicolumn{3}{|c|}{ Mean concn $/ \mathrm{m}^{3}$ of air } \\
\hline & & Coliforms & $\begin{array}{l}\text { E. coli } \mathrm{C} 3000 \\
\text { Phage* }^{*}\end{array}$ & $\begin{array}{c}\text { E. coli K12HfrD } \\
\text { Phage* }\end{array}$ \\
\hline $\begin{array}{l}25-39 \\
40-54 \\
55-69 \\
70-84 \\
85-99\end{array}$ & $\begin{array}{l}3 \\
1 \\
3 \\
7 \\
2\end{array}$ & $\begin{array}{l}1.1 \times 10^{2} \\
1.6 \times 10^{2} \\
7.5 \times 10^{1} \\
2.3 \times 10^{2} \\
7.5 \times 10^{1}\end{array}$ & $\begin{array}{l}1.8 \times 10^{-1} \\
3.5 \times 10^{-1} \\
3.2 \times 10^{-1} \\
2.9 \times 10^{-1} \\
4.8 \times 10^{-1}\end{array}$ & $\begin{array}{l}0.0 \\
5.0 \times 10^{-2} \\
1.7 \times 10^{-1} \\
3.1 \times 10^{-1} \\
4.8 \times 10^{-1}\end{array}$ \\
\hline Th & $\begin{array}{r}t_{(m-2)} \\
\text { not si } \\
\text { ine }\end{array}$ & $\begin{array}{ll}0 & \\
0.38 \quad t \\
\text { ant not }\end{array}$ & $\begin{array}{l}=0.34 \\
=1.35\end{array}$ & $\begin{array}{l}70 \\
67\end{array}$ \\
\hline
\end{tabular}

Table 9. Coliphage and coliform concentrations related to distance from airborne emission source

\begin{tabular}{|c|c|c|c|c|c|c|}
\hline \multirow[b]{2}{*}{ Organism } & \multirow[b]{2}{*}{$\begin{array}{l}\text { Plant } \\
\text { No. }\end{array}$} & \multicolumn{4}{|c|}{ Distance from source } & \multirow[b]{2}{*}{$\begin{array}{c}U \\
\text { value }\end{array}$} \\
\hline & & $\begin{array}{c}\text { No. } \\
\text { of } \\
\text { samples }\end{array}$ & $\begin{array}{l}5 \mathrm{M} \\
\underset{\text { Mean }}{\text { concn } / \mathrm{m}^{3}}\end{array}$ & $\begin{array}{c}\text { No. } \\
\text { of } \\
\text { samples }\end{array}$ & $\begin{array}{l}5 \mathrm{M} \\
\quad \begin{array}{l}\text { Mean } \\
\text { concn } / \mathrm{m}^{3}\end{array}\end{array}$ & \\
\hline $\begin{array}{l}\text { E. coli } \\
\text { C3000 } \\
\text { phage }\end{array}$ & 3,4 & 12 & $3.2 \times 10^{-1}$ & 4 & $2.4 \times 10^{-1}$ & $\begin{array}{c}17.50 \\
\text { (not } \\
\text { significant) }\end{array}$ \\
\hline $\begin{array}{l}\text { E. coli } \\
\text { K12HfrD } \\
\text { phage }\end{array}$ & 3,4 & 12 & $2.5 \times 10^{-1}$ & 4 & $1.6 \times 10^{-1}$ & $\begin{array}{c}21.00 \\
\text { (not } \\
\text { significant) }\end{array}$ \\
\hline $\begin{array}{l}\text { Coliform } \\
\text { bacteria }\end{array}$ & 3,4 & 12 & $2.1 \times 10^{2}$ & 4 & $1.4 \times 10^{1}$ & $\begin{array}{c}2.50 \\
\text { (significant) }\end{array}$ \\
\hline
\end{tabular}

than the same ratio in airborne emissions recovered from this source. That is, there appear to be greater numbers of coliform bacteria per coliphage in the liquid sewage than after droplets from this liquid become aerosolized.

A strong positive correlation, determined by the Spearman rank correlation coefficient $\left(r_{s}\right)$, as described by Siegel (1956), between windspeed and airbome coliform concentrations, is shown in Table 6 . However, no significant correlation is observed with the airborne coliphages of either strain of $E$. coli studied and windspeed. A significant inverse correlation is shown in Table 7 between airborne coliform concentration and ambient air temperature. That is, as the temperature increased, the aerosolized coliform recoveries decreased. No significant correlation could be detected between airborne coliphage concentrations and ambient air temperature.

Although it is difficult to separate the influence of relative humidity (RH) from other meteorological parameters, it is noted in Table 8 that a stronger positive correlation is observed between $\mathrm{RH}$ and airborne coliphage recoveries than between this parameter and aerosolized coliform levels. A significant correlation is found with the phages of $E$. coli $\mathrm{K} 12 \mathrm{HfrD}$ and RH.

Significantly lower coliform levels were observed at sampling distances greater than $5 \mathrm{~m}$ from the source 
than at nearer locations (see Table 9). No significant difference could, however, be detected between coliphage recoveries from the two general locations. That is, coliform recoveries significantly decreased at points farther from the emission source while coliphage levels remained more constant.

\section{DISCussion}

When comparing the levels of coliphages to animal virus in liquid sewage, it is not surprising that no airborne animal virus isolations were made from aerosols. The mean animal virus concentration per liter was about 3.6-3.7 logs lower than the mean coliphage level. On comparison of ratios of mean airborne coliphage isolations and their liquid sewage concentrations to animal virus liquid sewage levels, the expected airborne animal virus concentration would be approximately $6.2 \times 10^{-5}$ or $6.5 \times$ $10^{-5} \mathrm{MPN} \mathrm{m} \mathrm{m}^{-3}$, depending upon the phage host used for the estimate and assuming that these agents behave similarly in the environments studied. In other words, approximately $15 \times 10^{3}-16 \times 10^{3} \mathrm{~m}^{3}$ of air would need to be sampled to provide I detectable animal virus tissue culture unit under the conditions of this study. Based upon these estimates, the needed volume of air to be sampled and assayed to attain animal virus isolations within the range of those observed for coliphages would be at least $3.5 \times$ $10^{3} \mathrm{~m}^{3}$. In this study, the maximum volume of air sampled during any particular sampling run was $1.20 \times 10^{2} \mathrm{~m}^{3}$, and the sampled fluid available for animal virus assay was one-third or less of the total amount collected, since the remaining two-thirds was allocated to coliphage assay. Consequently, the level of sensitivity of the procedures used appears to be below that required for airborne animal virus isolations, under the conditions of sample collection and assuming that these viruses behave similarly to the coliphages isolated on specific host cells.

Wastewater treatment plants are continuous sources of airborne emissions to which downwind populations may be exposed. The significance of this exposure is related to the physical and biological stability in air of the potentially pathogenic emitted material and to the susceptibility, size, and density of an exposed downwind population. As this population increases in size and density, the probability of infection with airborne agents also increases. The minimal estimated levels of animal viruses in the airborne emissions studied in this investigation would produce considerable public health concern if they are shown to reach large susceptible downwind populations.

Airborne coliform/coliphage ratios were lower than liquid sewage coliform/coliphage ratios (see Table 5) at both plants examined. In other words, a higher number of coliforms per coliphage was recovered from the liquid sewage than from the air. Assuming both types of agents had the same opportunity for aerosolization and recovery, this observation indi- cates that the survival of airborne coliforms was lower than the survival of airborne coliphages.

Dispersion of airborne particles to sites remote from the source is influenced greatly by atmospheric stability. Stability of the atmosphere is highly dependent upon the vertical temperature gradient and the height of its distribution. Although rough estimates of stability may be made by visually observing certain climatic conditions, no attempt was made to include such estimates in this study. Since atmospheric stability could neither be controlled or measured, the results of this study must be interpreted with this in mind. Under natural conditions. such as those which exist in the field environment, it is difficult to separate the effects of individual meteorological parameters on the survival of airborne microorganisms. Although the conditions which existed during this investigation varied widely, attempts were made to determine whether correlation was observed between the recovery of certain airborne microorganisms and some meteorological parameters.

The present study showed that airborne coliform recoveries were significantly reduced under conditions of lower wind velocity (see Table 6), higher ambient air temperature (see Table 7), and at increased distances from the emission source (see Table 9). Coliphage recoveries were not found to be as strongly influenced by these conditions. Increases in wind velocity reduced the amount of time for which coliformcontaining particles remained airborne prior to collection. This condition resulted in decreased exposure of the coliform organisms to the stresses of the airborne state and, hence, may have enhanced their chances of being recovered at the sampling stations. Wind velocity may have been more critical to coliforms than to coliphages, since the former agents appear to be much less stable in aerosols. The negative effect on the survival of airborne coliforms with increases in ambient temperature from these plants agrees with the findings of Poon (1966) who showed that, under laboratory conditions, $E$. coli viability decreased logarithmically as temperature increased. He also demonstrated that this lower survival rate occurred at higher temperatures over a wide range of RH levels. Lower coliform concentrations at distances farther from this source were also shown by other investigators (Goff et al., 1973: Randall and Ledbetter, 1966). The lesser decrease for coliphages may be explained by the longer survival of coliphage agents compared to coliform bacteria in an aerosolized state. However, significant positive correlations were observed between the recoveries of coliphages of $E$. coli $\mathrm{Kl} 2 \mathrm{frD}$ and increases in $\mathrm{RH}$. Lower correlation was found between RH and E. coli C3000 phages, and no correlation could be made between coliform recovery and $\mathrm{RH}$ levels.

Although these observations may have been affected by additional environmental factors, they are consistent with the findings of other investigators who showed that coliphages are generally more stable at 
higher RH levels (Hatch and Warren, 1969; Dubovi and Akers, 1970: Benbough, 1971). and that no linear correlation exists between $E$. coli survival and $\mathrm{RH}$ (Webb, 1959).

The stability of organisms in the coliform group appears to be lower than that observed for certain viruses. Studies on the airborne stability of MS-2 by Dubovi and Akers (1970) showed, for example, that the survival of these agents was similar to that of polioviruses. Scarpino (1975) showed that poliovirus 1 , coxsackievirus A9. MS2, and $\mathrm{f}_{2}$ were much more resistant than coliforms to the extreme environmental influences of contact with hypochlorous acid than coliform bacteria. Geldreich and Clarke (1971) also cited evidence that certain enteric viruses are more resistant to chlorination than are coliform bacteria.

This evidence indicates that, under extreme conditions such as aerosolization or chlorination, both animal and bacterial viruses may persist longer as viable agents than coliform bacteria under similar conditions. It is desirable to attain an estimate of animal virus concentrations by direct assessment of their levels. The detection of coliforms or coliphages is, however, easier, faster, more economical, and probably more accurate than present methods of detecting low levels of animal viruses from the environment.

Based upon the above observations, the use of coliform bacteria as indicators of the viral contamination of these environments may result in an inaccurate assessment of the true presence or survival of viruses. Coliform determinations may not, therefore, be a valid or acceptable indicator of viral contamination.

No conclusive coliphage-to-animal virus ratio can be established from the present investigation. A pattern of Escherichia coli $\mathbf{B}$ coliphage-enteric virus ratio could not be established by Moore et al. (1974) during the monitoring of raw wastewater entering a Texas wastewater treatment plant. It was indicated by Vaughn and Metcalf (1975) that coliphages may be able to replicate in the sewage under certain conditions, thus upsetting any original ratio which might have existed with animal viruses. It is also likely, however, that the conditions which would permit coliphage replication in the environment might also permit coliform organisms to reproduce themselves, thus making these bacteria much less reliable indicator organisms.

It is, on the other hand, very unlikely that the conditions permitting significant replication of coliforms or of coliphages would exist in the airborne state. The air is a hostile environment to these organisms and survival depends upon a large number of factors, many of which have been discussed. The recovery of coliforms and coliphages downwind from a source indicates that they have been dispersed to that location and have survived aerosolization. Since certain coliphages were shown to survive this environment better than coliform bacteria, they should serve as better estimates of the dispersion of viable virus particles emitted from the source. Based upon evidence that certain coliphages, such as MS-2. are at least as hardy as certain animal viruses, such as polio, and that their airborne behavior is similar. certain bacterial viruses would serve as a better airborne viral indicator than coliforms. Determination of coliphage densities in a source and their subsequent airborne concentrations at an adjacent or downwind site. while establishing the animal virus levels of that source, would permit one to estimate the airborne animal virus levels which might exist, assuming similar survival patterns and without the use of more elaborate air sampling equipment.

\section{CONCLUSIONS}

1. Coliphage, animal virus ratios between liquid and aerosolized sewage indicate that wastewater treatment plants may be continuous sources of low level concentrations of animal virus aerosols.

2. Coliforms are an unreliable indicator of airborne viral contamination.

3. Coliphages are a more acceptable indicator of airborne viral contamination than coliforms in a sewage treatment environment.

Acknowledgements-This study was partially supported by: Graduate Research Training Grant 5T01 E500138, supported by the National Institute of Environmental Health Science; Office of Water Research and Technology Grant A-088-MICH, U.S. Department of the Interior; and DA Project 1T161101A91A, In-House Laboratory Independent Research through Dugway Proving Ground.

Thanks are extended to Mr. Edgar Larson, Fort Detrick, for providing needed equipment.

\section{REFERENCES}

Adams A. P. \& Spendlove J. C. (1970) Coliform aerosols emitted by sewage treatment plants. Science 169 , $1218-1220$.

Adams M. H. (1959) Bacteriophages. Interscience, New York.

Andersen A. A. (1958) New sampler for the collection, sizing, and enumeration of viable airborne particles. $J$. Bact. 76. 471-484.

Benbough J. E. (1971) Some factors affecting the survival of airborne viruses. J. gen. Virol. 10, 209-220.

Chang S. L. (1965) Statistic of the infective units of animal viruses. Transmission of Viruses by the Water Route. Edited by Berg G. Interscience. New York.

Davis J. E., Strauss J. H., Jr. \& Sinsheimer R. L. (1961) Bacteriophage MS-2: another RNA phage. Science 134, 1427.

deJong J. C., Harmsen M. \& Trouwborst T. (1973) The infectivity of nucleic acid of aerosol-inactivated poliovirus. J. gen. Virol. 18, 83-86.

Dubovi E. J. (1971) Biological activity of the nucleic acids extracted from two aerosolized bacterial virus. Appl. Microbiol. 21, 761-762.

Dubovi E. J. \& Akers T. G. (1970) Airborne stability of tailless bacterial viruses S-13 and MS-2. Appl. Microbiol. 19. 624-628.

Ehrlich R., Miller S. \& Idoine L. S. (1964) Effect of environmental factors on the survival of airborne T-3 coliphage. Appl. Microbiol. 12, 479-482. 
Fannin K. F., Spendlove J. C.. Cochran K. W. \& Gannon J. J. (1976) Airborne coliphages from wastewater-treatment facilities. J. appl. enciron. Microhiol. 31, 705-710.

Geldreich E. E. \& Clarke N. A. (1971) The coliform test: a criterion for the viral safery of water. In Proc. 13th Water Quality Conf. Virus and Water Qualit y: Occurrence and Control. University of Illinois, Urbana-Champaign.

Goff G. D., Spendlove J. C.. Adams A. P. \& Nicholes P. S. (1973) Emission of microbial aerosols from sewage treatment plants that use trickling filters. Hith Sert. Rep. 88. $640-652$ ?

Harstad J. B. (1965) Sampling submicron II bacteriophage aerosols. Appl. Microbiol. 13. 899-908.

Hatch M. T. \& Warren J. C. (1969) Enhanced recovery of $\mathrm{T}_{3}$ coliphage and Pasteurella pestis bacteriophage by means of a presampling humidification technique. Appl. Wicrobiol. 17. 685-689.

Hoff J. C. \& Jakubowski W. (1966) Application of an end point dilution method to bacteriophage assay. Appl Microbiol. 14. 468-469.

Kott Y. (1966) Estimation of low numbers of Escherichia coli bacteriophage by use of the most probable number method. Appl. Microbiol. 14, 141-144.

Kott Y., Ari B. H. \& Buras N. (1969) The fate of viruses in a marine environment. In Adrances in Water Pollution Research: Proc. 4th Int. Conf. Prague. Edited by Jenkins S. H. Pergamon Press. Oxford.

Kott Y.. Roze N., Sperber S. \& Betzer N. (1974) Bacteriophages as viral pollution indicators. Water Res. 8. $165-171$.

Lefler E. \& Kott Y. (1974) Virus retention and survival in sand. In V'irus Surtital in Water and Wastewater Systems. Edited by Malina J. F., Jr. and Sagik B. P., Water Resources Symp. No. 7. Center for Research in Water Resources. University of Texas at Austin.

Loeb T. (1959) Isolation of a bacteriophage specific for the $\mathrm{F}+$ and $\mathrm{Hfr}$ mating types of Escherichia coli $\mathrm{K}-12$. Science 131, 932-933.

Metcalf T. G. (1969) Discussion of Kott et al. (1969) In Advances in Water Pollution Research. Proc. 4th Int Conf.. Prague. Edited by Jenkins S. H. Pergamon Press, Oxford.
Metcalf T. G. Vaughn J. M. \& Stiles W. C. (1970) The occurrence of human viruses and coliphages in marine waters and shellfish. FAO Tech. Conf. Marine Pollution and its Effects on Living Resources and Fishing. FAO, Rome.

Moore B. E. D., Funderburg L., Sagik B. P. \& Malina J. F., Jr. (1974) Application of viral concentration techniques to field sampling. In Virus Survival in Water and Wastewater Systems. Edited by Malina J. F., Jr. and Sagik B. P. Water Resources Symp. No. 7. Center for Research in Water Resources. University of Texas at Austin.

Olivieri V. P. (1974) The mode of action of chlorine on $\mathrm{f}_{2}$ bacterial virus. Doctoral thesis, Johns Hopkins University.

Poon D. (1966) Studies on the instantaneous death of airborne Escherichia coli. Am. J. Epidemiol. 84. 1-9.

Randall C. W. \& Ledbetter J. O. (1966) Bacterial air pollution from activated sludge units. Am. ind. Hyg. Ass. J. 27. 506-519.

Rao V. C., Chandorkar U., Rao N. U., Kumaron P. \& Lakhe S. B. (1972) A simple method for concentrating viruses in wastewater. Water Res. 6. 1565-1576.

Scarpino P. V. (1975) Human enteric viruses and bacteriophages as indicators of sewage pollution. In Discharge of Sewage from Sea Outfalls. Edited by Gamegon A. L. H., pp. 49-61. Pergamon Press, Oxford.

Siegel S. (1956) Nonparametric Statistics for the Behavioral Sciences. pp. 116-127 and 202-213. McGraw-Hill, New York.

Standard Methods for the Examination of Water and Wastewater, (1971) I3th ed.. pp. 635 and 678-683. American Public Health Association. New York.

Vaughn J. M. \& Metcalf T. G. (1975) Coliphages as indicators of enteric viruses in shellfish and shellfish raising estuarine waters. Water Re's. 9, 613-616.

Wallis C., Henderson M. \& Melnick J. L. (1972) Enterovirus concentration on cellulose membranes. Appl. Microhiol. 23. 476-480.

Webb S. J. (1959) Factors affecting the viability of airborne bacteria. 1. Bacteria aerosolized from distilled water. Can. J. Microbiol. 5. 649-669. 